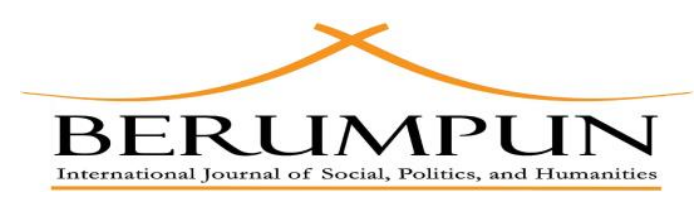

https://berumpun.ubb.ac.id/index.php/BRP
P-ISSN: 2622-8831

E-ISSN: $2622-8335$

\title{
CRIMINAL LIABILITY OF ROAD ORGANIZERS IN THE PERSPECTIVE OF LAW NUMBER 22 YEAR 2009 CONCERNING TRAFFIC AND ROAD TRANSPORTATION
}

\author{
Kabib Nawai ${ }^{1}$, Andi Najemi ${ }^{2}$ \\ 1,2,3Faculty of Law University of Jambi Indonesia
}

Corresponding Author: Andi Najemi, E-mail: andi.najemi66@yahoo.com

\begin{tabular}{l} 
ARTICLE INFO \\
Received: $12-08-2020$ \\
Accepted: $04-10-2020$ \\
Published: October 2020 \\
Volume: 3 \\
Issue: 2 \\
DOI: \\
https://doi.org/10.33019/berump \\
un.v3i1.39 \\
\hline KEYWORDS
\end{tabular}

ABSTRACT

Criminal liability, road organizers, Law Number 22 Year 2009

The specific goal of this research is to know and analyze the provisions of norms or legal norms relating to the criminal liability of road organizers from the dogmatic aspects of the law and legal principles and how criminal liability of the Road Organizers and Road Transportation according to Law Number 22 Year 2009 concerning Traffic and Road Transportation.

This research is normative. The data were obtained by a detailed analysis of legal materials, primary, secondary and tertiary law. The specification of this research is the pure legal research to get a picture of one problem, namely about the criminal responsibility of the road organizer from the perspective of Law Number 22 Year 2009, concerning Traffic and Road Transportation.

Through the legislative approach (normative approach), which is the approach to the applicable laws and regulations to obtain a basis for discussing issues related to traffic and road transport crimes, including legislation Law Number 22 Year 2009, concerning Road Traffic and Transport Law Number 38 of 2004, Concerning Roads, Government Regulation Number 43 of 1993 concerning Road Infrastructure and Traffic. The results of the study indicate that there is a blurring of norms in Law Number 22 Year 2009 , especially regarding the concept of road organizers as regulated in Article 24 and Article 273. as a result, the article cannot be operational. So that criminal liability for road organizers if they make a mistake on the formulas of article 24 and article 273 is difficult to account for. Although the organizer of the road as a legal subject if making a mistake should be responsible and can be held responsible based on the theory of strict liability and vicarious liability. The conclusion is that Law No. 22/2009 concerning Road Traffic and Transport does not regulate the concept of road organizers so that if a road organizer makes a mistake as regulated in Article 24 and Article 273 it is difficult to be accounted for, thus ensuring that there is a blurring of norms in The law and unworking.

\section{INTRODUCTION}

The existence of Law Number 22 Year 2009, concerning Traffic and Road Transportation has a very strategic function and purpose in handling traffic problems, especially those related to the land transportation system. Or in other words, Law Number 
https://berumpun.ubb.ac.id/index.php/BRP

22 Year 2009. Traffic and Road Transportation, in essence, is to regulate people's lives to be more orderly and orderly, especially in the field of traffic and road rules. Considering the nature of the traffic laws and road transport as mentioned above, there are two main functions of the existence of the traffic laws namely:

1. A social control function is a form of norms or rules that function to prevent and at the same time function to direct the community to behave properly and at the same time function to direct and correct deviant behavior.

2. A social engineering function aims to resolve when violations or conflicts occur so that what is the purpose of the law can be realized, realize the resolution of violations or conflicts that occur as a result of deviant acts or behavior by the norms and rules of law that are humane and justice.

Therefore, the existence of traffic regulations and road transport in addition to its function as social control and social engineering as mentioned above, it also has a strategic function on a national scale as well as an international dimension, because the legal rules contained in the law is applicable and bonded on all people including foreigners who are inside the territory of the Republic of Indonesia

The problem is whether the existence of traffic laws and road transportation as regulated in Law Number 22 Year 2009 can be regarded as a norm or good and operational legal norm. whether the function of social control and social engineering as the ultimate goal of the law can be realized?

To answer these questions certainly requires a deep and comprehensive analysis of the norms or legal norms contained in the law along with the amendment or analysis of other laws that are relevant to the issues that will be discussed in this study.

Law Number 22 Year 2009 is governing criminal liability for road organizers who have committed wrongdoing (criminal acts) along with criminal sanctions as implied in article 273 starting from paragraph (1) to paragraph (4) of the law these laws.

The criminal act regulated in Article 273 of Law Number 22 Year 2009 is a material criminal act, i.e.

1. criminal offenses committed by road organizers resulting in minor injuries and / or damage to vehicles and / or goods.

2. criminal offenses committed by the road organizer resulting in serious injuries and or damage to vehicles and / or goods

3. a criminal offense committed by a road organizer resulting in another death or

4. the criminal offense committed by the road organizer in the form of not giving a sign on the damaged road and has not been repaired ${ }^{1}$.

The criminal sanctions imposed in article 273 starting from paragraph (1) to paragraph (4) in the form of sanctions imprisonment or criminal fines alternatively,

\footnotetext{
${ }^{1}$ See the provisions of Article 273 of Law Number 22 Year 2009, concerning Traffic and Road Transportation
} 
https://berumpun.ubb.ac.id/index.php/BRP

imprisonment penalties, and criminal fines can be imposed one of two applicable criminal sanctions.

The problem is who is meant by the road organizer as regulated in article 273 of Law Number 22 Year 2009? to answer this question, it must be based on the existence of the law, whether in the law has provided a concept or understanding of the road organizer? because the formulation of the concept or understanding in law is very important, which serves to provide an explanation or give meaning to the propositions or words formulated in the article in the law so that the existence of the article becomes clear and unambiguous or multiple interpretations. Usually, the concepts or meanings in the law are set in Chapter I, Paragraph I on Definitions. For example, in article 273 of Law Number 22 Year 2009 concerning Road Traffic and Transport, criminal sanctions in the form of imprisonment and fines for road organizers committing crimes, but in Chapter I Paragraph I which regulates concepts or understandings, there is no formulation or understanding of who is meant by the organizer of the road, wherein Article 273 of Law Number 22 Year 2009 explicitly regulates criminal sanctions when the road organizer commits an error or a criminal offense.

Therefore, Law Number 22 Year 2009 concerning Traffic and Road Transportation can be said to be a law that is not operational, especially relating to criminal acts regulated in Article 273 starting from paragraph (1) to paragraph (4). Or in other words in Law Number 22 Year 2009 there is a void of norms, especially related to the formulation of norms regulated in article 273 which provides criminal sanctions to road organizers. "The road organizer is obliged to immediately repair the damaged road that can result in a traffic accident, to prevent it, the road organizer must give a sign."2

If it is analogous that what is intended by the road organizer is the government, "based on this law the guidance in the field of Road Traffic and Transport is carried out jointly by all relevant agencies (stakeholders) in government affairs in the field of road infrastructure"3, or by the ministry responsible for the road sector; CQ. The ministry in charge of road construction (The Ministry of Public Works and Public Housing or PUPR) at the Central Level or the Public Works Office at the regional level (Province, Ko ta Regency). Then a new problem will emerge, namely, whether the Ministry of Public Works and Public Works Offices at the Provincial, Regency, and City Levels, which notes that as a State institution may be subject to imprisonment? bearing in mind that the formulation of criminal sanctions formulated in article 273 is in the form of sanctions of imprisonment and alternative fines so that they will also cause problems in their application.

Indeed, it can be found about the concept or understanding of the road organizer in Law Number 38 of 2004 concerning Roads, wherein article 1 number 14 it is stated explicitly "The organizer of the road is the party that carries out the arrangement, guidance, construction, and supervision of the road following its authority"4. in the sense of the road

\footnotetext{
2 See the formulation of Article 24 of law Number 22 Year 2009, concerning Traffic and Road Transportation

${ }^{3}$ Feti Rakhmani, Government Liability Due to Road Damage to Motor Vehicle Accidents based on Article 238 of Law No. 22 of 2009 concerning Traffic and Road Transportation

Road Transportation, 2017 p. 4 Beritagresik.com

${ }^{4}$ The formulation Article 1 number 14 of Law Number 38 concerning Road
} 
https://berumpun.ubb.ac.id/index.php/BRP

organizer as formulated in Law Number 38 of 2004, there is still a blurring of norms, because there is no clarity on who is authorized to make arrangements, guidance, construction and supervision of roads.

The question still arises whether the concept of the road organizer regulated in article 1 number 14 of Law Number 38 of 2004, can be used as an operational basis in the application of criminal sanctions regulated in article 273 of Law Number 22 Year 2009?

Based on the aforementioned thoughts, the researcher intends to conduct research based on normative studies, concerning the criminal responsibility of the road organizer in the perspective of Law Number 22 of2009 concerning Traffic and in particular from the perspective of criminal law studies.

What has been described in the background above is a central issue and a central issue that will be developed into the basis of the object of this research, especially concerning criminal liability of road organizers when violating the norms of the rule of law stipulated in Article 273 of the Law Number 22 Year 2009 concerning Road Traffic and Transportation. Thus, the formulation of the problem to be examined is:

1. What is the criminal liability of the road organizer according to Law Number 22 Year 2009, Regarding Traffic and Road Transportation?

2. What is the policy that will be carried out when the Law is not operational due to the absence of the norm?

\section{METHODOLOGY}

This research is normative, the use of this method is done through the study of legal materials, both primary legal materials, secondary legal materials tertiary legal materials. The specification of this research is the pure legal research to obtain a description of one problem, namely the criminal responsibility of the road organizer from the perspective of Law Number 22 of 2009, concerning Traffic and Road Transportation. By going through the legislative approach (normative approach), which is the approach to the applicable laws and regulations to obtain a basis or basis in discussing issues, including legislation Law Number 22 of 2009, concerning Traffic and Road Transportation Law Number 38 Year 2004 concerning Roads, Government Regulation Number 43 Year 1993 concerning Road Infrastructure and Traffic. related to traffic and road transport crimes.

\section{DISCUSSION}

\section{Criminal liability of road organizers according to Law Number 22 Year 2009, Regar ding Road Traffic and Transportation.}

\section{A. The Concept of Road Organizers in Law Number 22 Year 2009, Regarding Road T raffic and Transportation.}

Law Number 22 Year 2009 concerning Road Traffic and Transport, is a renewal of Law Number 14 of 1992 concerning Road Traffic and Transportation. The basic concept of this $\mathrm{L}$ aw is "that Traffic and Road Transportation as part of the national transportation system $\mathrm{m}$ ust develop their potential and role to realize security, safety, order and smoothness of road traffic and transportation to support economic development and regional development". To 
https://berumpun.ubb.ac.id/index.php/BRP

realize this security, Law Number 22 of 2009 regulates who can be punished, what actions a nd sanctions can be imposed. One of the legal subjects regulated in Law Number 22 Year 20 09 is Road Administrators. Article 24 paragraph (1), the Organizer of the Road shall be oblig ed immediately and properly to repair the damaged road which can occur a traffic accident. Next, paragraph (2) If repair of a damaged road as referred to in paragraph (1) cannot yet b e carried out, the organizer of the road shall provide a sign on the damaged road to prevent the occurrence of a traffic accident.

The question is who is the road organizer? Factually, the Law Number 22 Year $2009 \mathrm{~d}$ oes not provide a concept/understanding of the "Road Organizer", both in Chapter I Article 1 About the definition, and in the explanation of Article by Article. To answer the above que stions, an in-depth analysis is needed relating to the norms or legal norms regulated in Law Number 22 Year 2009 Concerning Road Traffic and Transport and its derivatives, it is even possible to study other relevant laws that may be used as material analysis.

In Law Number 22 Year 2009, it can be said to be a law that is not good because of the requirements of the good law according to Law Number 12 of 2011, concerning the Formati on of Laws and Regulations. One of the principles of the formation of good laws and regulati ons is as stipulated in Article 5, namely:

"In forming legislation, it must be based on the principle of the establishment of good l egislation, which includes:

a. clarity of purpose;

b. the appropriate institutional or forming authority;

c. match between type, hierarchy, and material content;

d. can be implemented;

e. usability;

f. clarity of the formula; and

g. openness."

Article 4 Paragraph (2) PERMA (Rule of The Indonesia Supreme Court) Number. 13 Year 2016 "In imposing a crime against a Corporation, the Judge may assess the Corporation's error as referred to in paragraph (1), including:

a. Corporations gain benefits or advantages from these crimes or those criminal acts committed in the interests of the Corporation;

b. Corporations allow criminal acts to occur; or

c. The corporation does not take the steps necessary to prevent a greater impact.

Law Number 22 Year 2009, has not met the principles of good legal requirements as $\mathrm{s}$ pecified in Article 5 of Law Number 12 of 2011, especially in letters d, e and letters f. As a re sult, the criminal formulation as stipulated in Article 24 paragraph (1) and paragraph (2) an $\mathrm{d}$ Article 273 if a violation occurs, will cause problems related to law enforcement, because of the lack of clarity about the concept of the road organizer as a legal subject. Because the $f$ ormulation of the concept or understanding in law is very important, which serves to provi de an explanation or give meaning to the propositions or words formulated in the article in the law so that the existence of the article becomes a clear and unambiguous or multi-interp retation. 
https://berumpun.ubb.ac.id/index.php/BRP

Usually, the concepts or definitions in the law are set in Chapter I, Paragraph I on Defi nitions. For example, article 273 of Law Number 22 Year 2009 concerning Traffic and Road Transportation has given criminal sanctions in the form of imprisonment and fines for road organizers who committed crimes, but in Chapter I Paragraph I, there is no concept about $t$ he definition of road organizer itself. Article 273 of Law Number 22 Year 2009 only express ly regulates criminal sanctions when a road organizer commits an error or a criminal offens e. In the absence of understanding or concept of the road organizer, it creates confusion in $t$ he application of criminal sanctions when the organizers make a mistake.

Therefore, Law Number 22 Year 2009 concerning Traffic and Road Transportation ca $\mathrm{n}$ be said to be a law that is not operational, specifically relating to criminal acts regulated in Article 24 paragraph (1) and paragraph (2) and Article 273 starting paragraph (1) up to par agraph (4). With the lack of clarity in the law, the new traffic law regulates criminal provisio ns. However, the Act only mentioned as the organizer of the road, but not directly mentione $\mathrm{d}$ the institutions. Thus the law can be said to be still unclear about who is responsible for th e administration of the road. 'Or in other words in Law Number 22 Year 2009, there is a blu rring of norms, especially related to the formulation of norms regulated in article 273 which provides criminal sanctions to road organizers. "The road organizer is obliged to immediate ly repair the damaged road that can result in a traffic accident, to prevent it, the road organi zer must give a sign".

Provisions of article 273 of Law No. 22 of 2009, as mentioned above, contains the follo wing elements:

1. Subjective elements, namely: Organizer of the Road.

2. The objective element: not immediately and properly repairing damaged roads; re sulting in a traffic accident in minor injuries and/or damage to vehicles and/or goo ds.

In the first element, Law No. 22 of 2009 does not explain who is meant by the organize $r$ of the road. Indeed, it can be found about the concept or understanding of the organizers 0 f the road in Law Number 38 of 2004 concerning roads, article 1 number 14 is stated explici tly "Road investigators are parties who conduct arrangements, guidance, construction and s upervision of roads by their authority ". Provisions in Article 1 number 14 of Law No. 38 of 2004 does not provide a clear understanding of road organizers but rather regulates the du ties and authority of road organizers. Thus the understanding of road organizers formulate d in Law Number 38 of 2004, there is also still a blurring of norms, because there is no clarit $y$ about who is authorized to make arrangements, guidance, construction, and supervision 0 f roads. Therefore the concept of the road organizer as formulated in Law Number 38 of 20 04 cannot also be used as a conceptual basis as a legal subject in Law Number 22 Year 2009 , Regarding Road Traffic and Transportation.

\section{B. Criminal Liability of Road Organizers.}

Road organizers are criminal offenses who have rights and obligations and legal respo nsibilities or the rule of law. The intended legal responsibility is a consequence as a result 0 $f$ an error against violations of norms or legal norms that should be held responsible by the perpetrators when the perpetrators make mistakes that meet the criminal element. Thus "e rror is placed as a determining factor for criminal liability and is not merely seen as a menta l element in criminal acts." "A person found guilty of wrongdoing is a matter of criminal lia 
https://berumpun.ubb.ac.id/index.php/BRP

bility."

To be able to impose criminal sanctions on perpetrators, the legal rules regarding crim inal liability serve as determinants of the conditions that must exist in the perpetrators so $t$ hat they are valid if the perpetrators are given criminal sanctions as a result of their mistak es. "Criminal liability relating to the matter of the makers of a criminal offense, rules regardi ng criminal liability are regulations on how to treat those who violate obligations

To be able to impose criminal sanctions on perpetrators for committing crimes, the le gal rules regarding criminal liability serve as determinants of the conditions that must exist in the perpetrators so that they are valid if the perpetrators are given criminal sanctions as a result of their mistakes. "Criminal liability relating to the matter of the makers of a crimin al offense, rules regarding criminal liability are regulations on how to treat those who violat e obligations".

Law Number 22 Year 2009 concerning Road Traffic and Transportation, in article 273 regulates the criminal liability of road organizers, in the event of an error made by road org anizers which resulting traffic accidents and accident victims, the road organizer is obliged $t$ o take responsibility for the mistakes made. The problem is whether the road organizer can be held accountable for his mistakes as the norms formulated in Article 24 and Article 273 o f Law Number 22 Year 2009? Is the organizer of the road can be said as a legal subject.

In the science of criminal law, criminal liability is defined as a criminal liability or refe rred to by other terms criminal responsibility is a form of responsibility for mistakes comm itted by perpetrators of crime, where the act he committed is an act that the community con siders to be a despicable act, therefore, these actions must be held responsible to the perpet rators or legal subjects. There are several criminal liability requirements, namely:

Capable of being responsible, that the perpetrators can be legally accounted for, the co ncept of being able to be responsible is related to the concept of punishment, meaning that $t$ he perpetrators of criminal acts can be subject to criminal sanctions as long as the acts have fulfilled the elements of the norms of criminal law which are violated.

There is an error, the intention is that there is an element of intent or negligence of th e perpetrators of the crime, the intentional or negligence of the perpetrators of the crime $\mathrm{m}$ ust understand the element of consciousness or awareness with the possibility.

There is no excuse for forgiveness, that the form of the ability to be held responsible fo $r$ a crime directed at the perpetrators of a crime, or in other terms to the perpetrators of a $c$ riminal act is deemed incapable of being responsible due to several factors attached to the $p$ erpetrator.

Basically, there are two forms of mistakes in criminal law, namely in the form of intent and negligence. The difference between the two forms of error is that "the intentional behav ior of the offender does indeed violate the norm, whereas in neglect the inner attitude of the perpetrator simply does not heed the legal prohibition so he is not careful in carrying out an act that gives rise to a prohibited state." As a form of error in criminal law, the difference be tween the two is only in quality, so that the road organizer does not immediately repair dam aged roads causing traffic accidents as regulated in Law No. 22 of 2009 concerning Traffic T ransportation.

Therefore, the road organizers that do not repair damaged roads immediately can be $s$ aid to have the ability to be responsible, this is because the road organizers make mistakes $\mathrm{i}$ 
https://berumpun.ubb.ac.id/index.php/BRP

$\mathrm{n}$ the form of:

a. Do not repair damaged roads immediately resulting in traffic accidents;

b) Do not give warnings or signs on damaged roads that have not been repaired;

c) Does not meet the security and safety standards for traffic road.

Although it has been clearly stated in the provisions of Article 273 of Law Number. 22 of 2009 concerning Road Transportation Traffic that a road organizer can be convicted of a criminal offense, but in that law, there is no provision for who is meant by the road organize $r$, either in the formulation of the concept or article by article explanation. Therefore, Article 24 juncto (in correlation with). Article 273 of Law Number 22 Year 2009 concerning Traffic and Road Transportation is an article that is not operational because there are still vague $n$ orms

\section{c. Are Road organizers as a legal subject?}

In several laws and regulations in Indonesia, the corporation has been treated as a leg al subject in addition to the subject of human law, but the existence of the subject of corpora te law is different from the subject of human law. As a legal subject, the corporation is possi ble in carrying out its activities in carrying out deviant actions that are organizational. "The refore, to understand corporate crime, as an organized crime, which is a crime that occurs i $\mathrm{n}$ the context of a relationship that is loaded with hopes and desires among stakeholders na mely the commissioners, the board of directors, and managers on one side and between the central office, parts, and branches on the other side."

With the acceptance of the corporation as a subject of criminal law, it turns out to caus e problems in our criminal law, especially those concerning criminal liability issues at the c orporation. The important thing that must be considered concerning the element of error, a $\mathrm{s}$ a form of corporate criminal responsibility can be made possible, whether the element of $\mathrm{e}$ rror in the corporation can be equated as in humans, whether the corporation can be convic ted as a human being or not. Considering that a corporation is a form of a legal entity that $\mathrm{m}$ oves because there is a mover in the form of an "administrator", namely a human being. Con sidering that the form of criminal sanctions in the field of criminal law is not only criminal s anctions for fines but there are other forms of sanctions in the form of loss of independence namely prison and confinement even sanctions in the form of capital punishment sanctions, such sanctions may not be imposed on corporations, to determine Corporate criminal liabili ty commonly uses the doctrine or principle of liability without errors (strict liability) and vi carious liability. "The principle of strict liability in corporate responsibility does not need to prove the existence of an element of error in the corporation and the vicarious liability prin ciple states that corporations can be held responsible for the actions of others in the enviro nment of their business activities." The problem is the extent to which corporate mistakes c an be limited by adhering to the doctrines of strict liability and vicarious liability

Referring to the subtitles above, are road organizers legal subjects? to be able to say th at road organizers as legal subjects need to pay attention to several clauses as well as corpo rations. Considering the corporation as a legal entity that is driven by (human) managemen $t$, so is the case with the road organizer, except that the difference between the road organiz er is an institution that is within the scope of government both the central and regional gov ernments responsible for road construction and repair, which in this case is the Ministry of Public Works and Public Works in the Provincial Government and Regency / City Governme nt which is organizationally and structurally controlled by humans as responsible officials $\mathrm{i}$ 
https://berumpun.ubb.ac.id/index.php/BRP

$\mathrm{n}$ the scope of their responsibilities by their respective positions and authorities.

The issue is regarding Road Organizers who are subject to criminal law, where there a re criminal sanctions if "the road organizer does not carry out obligations towards damaged roads resulting in traffic accidents. If the obligation is not carried out resulting in a traffic ac cident, which results in other people with minor injuries, serious injuries, even death and $d$ amage to property there is an alternative sanction of imprisonment and fines." Considering this provision is a responsibility that must be carried out, then in the event of a traffic accid ent that results in a legal consequence, the road organizer must be held criminally responsi ble as well as a form of criminal liability for mistakes made.

Thus, road organizers as legal subjects should be criminally accountable by referring $t$ o the principle of strict liability and vicarious liability, meaning that the form of criminal lia bility of road organizers according to the principle of 'stric liability 'does not need to prove $t$ he existence of an element of error either intentional or negligence. Because the organizer o $\mathrm{f}$ the road as a government agency should be responsible for the obligations attached to it. $\mathrm{L}$ ikewise according to the principle of vicarious liability that the organizer of the road can be held responsible for acts that are indeed given authority and responsibility by the state. As $t$ he person in charge and at the same time as the holder of the mandate, the road organizer $s$ hould carry it out with a sense of responsibility based on the rules of law and procedures as they should without conditions. The problem is that: First, the road organizer as a governm ent institution is bound by procedures and governance and financial mechanisms related to budget issues that can sometimes hinder the process of carrying out work according to the $r$ esponsibilities it carries aside from weather factors. Second, in the event of an accident that results in the occurrence of legal events as determined in Article 24 Jo Article 273 of Law N umber 22 Year 2009, the road organizer must be held criminally responsible, with criminal sanctions as formulated in Article 273 of Law Number 22 Year 2009, Regarding Traffic and Road Transportation in the form of an alternative jail sentence or fine.

\section{CONCLUSION}

Based on the discussion above, it is can be concluded that in Law Number 22 Year 1999, regarding Road Traffic and Transportation, does not provide an explanation or concept regarding road organizers, so when there are norms are governing criminal liability towards road organizers, as regulated in Article 24 and Article 273, there are obstacles and gaps in the implementation. From the aspect of criminal liability, the road organizer is identical to the corporation, only the management system distinguishes it from the corporation in general. The management system in the road organizer is bound by structural bureaucracy both at the central and regional levels. However, if there is an error on the road, the road organizer should still be able to take responsibility by referring to the theory of stric liability and vecarius lebility. Therefore, Law Number 22 Year 2009 Concerning Road Traffic and Transportation, there are unclear norms, specifically regarding the concept of road organizers. Consequently, when an error occurs as a result of a damaged road and resulting in a traffic accident, causing physical loss to the victim, minor injuries, severe injuries, even death and damage to property, it is difficult to be implemented, due to the provisions of Article 24 and Article 273 of the Law Law Number 22 of 2009 is a non-operational provision. The suggestion for the problem according to the author is that there are alternative solutions by 
https://berumpun.ubb.ac.id/index.php/BRP

making derivatives in the form of Government Regulation concerning the Implementation of Law Number 22 Year 2009 Regarding Road Traffic and Transportation so that there is a solution to the follow-up to the clarity of norms on the concept of the road organizers as an alternative step in resolving the existence of the ambiguity of the norms article 24 and article 273.

\section{REFERENCES}

Hatrik, H. 1996. Asas Pertanggungjawaban Korporasi Dalam Hukum Pidana Indonesia. Jakarta: Raja Grafindo Persada.

Huda, C. 2008. Dari Tiada Pidana Tanpa Kesalahan Menuju Kepada Tiada Pertanggungjawaban Pidana Tanpa Kesalahan. Edisi Pertama. Jakarta: PT. Prenada Media.

Ibrahim, J. 2007. Teori dan Metodologi Penelitian Hukum Normatif. Surabaya: Bayumedia Publishing

Sahuri, L. 2003. Pertanggungjawaban Korporasi Dalam Perspektif Kebijakan Hukum Pidana Indonesia. Disertasi Doktor Pascasarjana Universitas Airlangga. Surabaya.

Muladi \& Priyatno, D. 1991. Pertanggungjawaban Korporasi Dalam Hukum Pidana. Bandung: STHB.

Reksodiputro, M. B. 1989. Pertanggungjawaban Pidana Korporasi dalam Hukum Pidana Korporasi. FH UNDIP, Semarang.

Setiyono. 2004. Kejahatan Korporasi. Edisi Kedua. Malang: Bayumedia Publishing.

\section{Law}

Law Number 22 Year 2009 Concerning Traffic and Road Transportation.

Law Number 38 Year 2004 Concerning Road.

\section{Journal}

Agustinus Pohan "Unsur Kesalahan Dalam Pertanggungjawaban Pidana Korporasi Disampaikan Dalam "Public Seminar on Corporate Criminal Liabilities" Jakarta 21 Februari 2017

Bismar Nasution, Kejahatan Korporasi, hal.6. http://bismar.wordpress.com/ 2012/10/23/Kejahatan-Korporasi/.

Hikmahanto Juwana, SH., LL.M., Ph.D, Penegakan Hukum Dalam Kajian Law \& Development, http://www.ui.edu/indonesia/main.php?hlm=berita\&id=2006-03-28\%2016:0. 
BERUIMPUN

International Journal of Social, Politics, and Humanities

https://berumpun.ubb.ac.id/index.php/BRP

P-ISSN: 2622-8831

E-ISSN: 2622-8335

Widyawati Budiningsih, SH., MHum "Pertanggungjawaban Pidana Penyelenggara Jalan

Vol. 3 No. 2 October 2020 Terhadap Korban Akibat Kerusakan Jalan Jurnal Hukum, Vol. XIX, No. 19, Oktober 2010:33 - 48 ISSN 1412 - 0887

Jimly Ashidique Penegakan Hukum, http://www.solusihukum.com/artikel/artikel49.php 